\title{
LARYNGOLOGY
}

\section{Organ preservation and oncological outcomes in early laryngeal cancer: a propensity score-based study}

\section{Preservazione d'organo ed esiti oncologici nel carcinoma laringeo in stadio iniziale: uno studio basato sul punteggio di propensione}

\author{
Genival Barbosa de Carvalho', Hugo Fontan Kohler ${ }^{1}$, Julia Bette Homem de Mello',3, Renan Bezerra Lira', \\ Antonio Cássio de Assis Pellizzon², José Guilherme Vartanian', Luiz Paulo Kowalski1,4 \\ ${ }^{1}$ Head and Neck Surgery and Otorhinolaryngology Department, A. C. Camargo Cancer Center, São Paulo, Brazil; ${ }^{2}$ Radiation \\ Oncology Department, A. C. Camargo Cancer Center, São Paulo, Brazil; ${ }^{3}$ Carcinogenesis Molecular Program, National Institute \\ of Cancer - INCA, Rio de Janeiro, RJ, Brazil; ${ }^{4}$ Head and Neck Surgery Department and LIM 28, University of Sao Paulo Medical \\ School, Sao Paulo, Brazil
}

\section{SUMMARY}

Background. The rates of laryngeal preservation according to therapeutic modality in patients with initial laryngeal squamous cell carcinoma (LSCC) are still controversial. This study evaluated the rates of laryngeal preservation in patients who underwent treatment with surgery or radiotherapy.

Methods. This retrospective cohort study evaluated 151 patients with stage I or II LSCC. Ninety-six patients were matched using a propensity-score and outcomes were compared within this group.

Results. Regarding overall, cancer-specific survival and larynx preservation, no differences were observed according to the therapeutic modalities, but patients who underwent radiotherapy had a higher rate of local recurrence than those who underwent surgery. Patients classified as ASA 3 or 4 and treated with radiotherapy showed a tendency of higher risk of larynx loss.

Conclusions. Patients with stage I or II laryngeal tumours can be submitted to surgery or radiotherapy with similar rates of laryngeal preservation.

KEY WORDS: laryngeal neoplasms, laryngeal surgery, laryngeal radiotherapy, organ preservation

\section{RIASSUNTO}

Background. Le percentuali di conservazione della laringe nei diversi trattamenti dei pazienti affetti da carcinoma a cellule squamose della laringe iniziale (LSCC) sono ancora controversi. Questo studio ha valutato i tassi di preservazione laringea nei pazienti sottoposti a trattamento chirurgico o radioterapia.

Metodi. Questo studio di coorte retrospettivo ha valutato 151 pazienti con LSCC, stadio I o II. Novantasei pazienti sono stati abbinati utilizzando un punteggio di propensione e $i$ risultati sono stati confrontati all'interno di questo gruppo.

Risultati. Per quanto riguarda la sopravvivenza globale, cancro-specifica e la conservazione della laringe, non sono state osservate differenze in base alle modalità terapeutiche, ma i pazienti sottoposti a radioterapia avevano un tasso di recidiva locale più elevato rispetto a quelli sottoposti a intervento chirurgico. Inoltre, i pazienti classificati come ASA 3 o 4 e trattati con radioterapia hanno mostrato una tendenza a un rischio maggiore di perdita della laringe.

Conclusioni. I pazienti con tumori laringei in stadio I o II possono essere sottoposti a chirurgia o radioterapia con tassi di conservazione laringea simili.

PAROLE CHIAVE: neoplasie laringee, chirurgia laringea, radioterapia laringea, preservazione d'organo
Received: May 19, 2020

Accepted: October 13, 2020

\section{Correspondence}

Genival Barbosa de Carvalho

Head and Neck Surgery and Otorhinolaryngology

Department, A.C. Camargo Cancer Center

Rua Professor Antonio Prudente, 211, Liberdade 01509-900, São Paulo, Brazil

Fax +55 1132776789

E-mail: genibarbo@gmail.com

Funding

None.

Conflict of interest

The Authors declare no conflict of interest.

How to cite this article: de Carvalho GB, Kohler HF, de Mello JBH, et al. Organ preservation and oncological outcomes in early laryngeal cancer: a propensity score-based study. Acta Otorhinolaryngol Ital 2021;41:317-326. https://doi. org/10.14639/0392-100X-N0870

() Società Italiana di Otorinolaringoiatria e Chirurgia Cervico-Facciale

\section{(c) (1) $(9)$}

This is an open access article distributed in accordance with the CC-BY-NC-ND (Creative Commons Attribution-NonCommercial-NoDerivatives 4.0 International) license. The article can be used by giving appropriate credit and mentioning the license, but only for non-commercial purposes and only in the original version. For further information: https:// creativecommons.org/licenses/by-nc-nd/4.0/deed.en 


\section{Introduction}

The treatment of patients with early-stage (stages I and II) laryngeal squamous cell carcinoma (LSCC) is usually based on a single modality, such as surgery or radiotherapy, with similar overall survival rates ${ }^{1-5}$. Studies evaluating organ preservation for these patients have reported controversial results. The systematic review by Warner et al. (2014) documented only one prospective, randomised study comparing surgery and radiotherapy in 234 patients with earlystage disease (all glottic tumours). They demonstrated that patients submitted to radiotherapy showed higher rates of local recurrences than those submitted to surgery. However, no information about organ preservation rates was available for either group, and no significant differences were observed in overall and cancer-specific survival rates ${ }^{6}$. Some meta-analyses and systematic reviews including patients with glottic tumours at clinical stages Tis/T1/T2 and N0 have reported that laryngeal preservation rates are higher in patients who underwent transoral laser surgery than in patients submitted to radiotherapy ${ }^{7-9}$. However, the study by Jones et al. (2004) on 488 larynx cancer patients at clinical stages I and II did not demonstrate a significant difference between overall and cancer-specific survival and local recurrence rates between treatments. The authors also described higher rates of regional recurrence and worse vocal outcomes for patients submitted to surgery than those submitted to radiotherapy; however, they did not evaluate the organ preservation rates of these patients ${ }^{3}$. Most of these studies have some limitations, such as the heterogeneity of treatments, follow-up time, and selection bias due to patient or medical decisions.

Considering these controversial results, the present study evaluated laryngeal preservation rates and survival in patients with laryngeal epidermoid carcinoma at stage I or II treated with surgery (transoral or conventional) or radiotherapy. A propensity score (PS) analysis was performed to reduce the influence of selection bias in outcome analysis.

\section{Materials and methods}

\section{Patients, clinical and histopathological characterisation}

This is a retrospective cohort study and included 151 patients with cT1N0 or cT2N0 LSCC treated with curative intent from January 1995 to December 2014 at A.C. Camargo Cancer Center (Brazil). The study was approved by the ethics committee (2118/15). Inclusion criteria included previously untreated LSCC at clinical stages I or II and treated with curative intent. Exclusion criteria included patients with other synchronous, prior malignancies in the head and neck and those whose medical records lacked in- formation relevant to the study or a follow-up time less of than 6 months.

All patients were offered both therapeutic modalities. However, no resources for transoral laser surgery were available at our facility until 2014 and many patients refused conventional partial laryngectomy, due to nasoenteral tube, or tracheostomy. Therefore, most were treated with radiotherapy. Patients were followed every 1 to 3 months in the first year, every 2 to 4 months in the second year, every 6 months from 3 to 5 years and thereafter every 12 months. Follow-up was performed with videonasolaryngoscopy or laryngoscopy and computed tomography (CT) or magnetic resonance imaging (MRI) of the neck.

Clinical and pathological data were obtained from medical charts. A review of data from clinical locoregional physical examination, video laryngoscopy and direct laryngoscopy data was carried out to characterise tumour staging. All participants were submitted to MRI or CT of the neck no more than six weeks before initiation of treatment. In addition, participants were submitted to a simple chest X-ray or CT scan for detection of distant metastases or lung cancer. All patients were re-staged in accordance with the Classification of Malignant Tumours of the UICC $\left(8^{\text {th }}\right.$ Edition $){ }^{10}$. Patients with permanent tracheostomy, recurrent aspiration pneumonia in the last year of follow-up, percutaneous gastrostomy, or nasoenteral tube were considered with loss of laryngeal function.

To reduce selection bias from non-random allocation to different treatments, we used propensity-score matching. The variable used for propensity-score calculation was clinical stage and treatment. Patients were matched according to the nearest-neighbor algorithm with a 0.02 caliper. The pvalue for statistical significance was 5\%. Survival curves and laryngo-oesophageal dysfunction were analysed using the Kaplan Meier method, assessing statistical significance between groups with the log-rank test. Cox regression was used to estimate the risk factors for clinical outcomes, with its influence evaluated by hazard ratio (HR) and 95\% confidence intervals. Statistical analysis was performed using SPSS software (v. 21.0; SPSS, Chicago, IL, USA).

\section{Results}

\section{Clinical data}

According to inclusion and exclusion criteria, 151 patients were included in the study. Among these, 124 patients were men $(82 \%)$ and the median age was 61 years (range 22-77 years). The majority of the patients $(\mathrm{n}=135 ; 89 \%)$ had previous tobacco exposure and $92(58.5 \%)$ were consumers of alcoholic beverages. Sixty-six patients $(45.2 \%)$ had comorbidities at diagnosis, with hypertension $(n=14 ; 9.2 \%)$ 
and type II diabetes $(\mathrm{n}=7 ; 4.2 \%)$ being the most frequent. Thirty-five patients $(41.2 \%)$ were in the normal weight range considering body mass index (BMI) and most were classified as ASA $2(\mathrm{n}=72 ; 76.6 \%)$. The follow-up period ranged from 6 to 276 months (median of 55 months). Twenty-three (15.2\%) patients were lost to follow up, with a median time of 34 months (ranging from 18 days to 97 months). There were no significant differences between patients lost to follow-up according to treatment.

Among these patients, 96 were matched after PS analysis. These groups were used to evaluate the association of treatment modality with clinical outcomes and functional larynx preservation rates.

Of the 48 patients submitted to surgery, $37(77,1 \%)$ underwent a conventional partial laryngectomy, 12 (25\%) underwent frontolateral partial laryngectomy, 11 (22.9\%) transoral endoscopic surgery resection and $39(81,2) \%$ ) had resection with free margins. After pathological analysis, three of $18 \mathrm{cT} 1 \mathrm{a}$ patients were upstaged to pT2. From 28 tumours staged as cT2, six (21.4\%) were staged as pT1 and six (21.4\%) as pT3 due to paraglottic space invasion. No patient with a transglottic tumour was submitted to surgery. Among these patients, eight (16.6\%) underwent postoperative adjuvant radiotherapy by positive margins.

In patients submitted to radiotherapy, the final dose ranged from 51.7 to $70.4 \mathrm{~Gy}$ (median, $66 \mathrm{~Gy}$ ) for cT1a patients, 50.5 to 70 Gy (median, 64.2 Gy) for cT1b patients and 54 to 74.4 Gy (median, $69.7 \mathrm{~Gy}$ ) in cT2 patients. Radiotherapy treatment time was 51 days, ranging from 26 to 85 days. Most patients presented acute side effects $(n=45 ; 95.8 \%)$, with radiodermatitis grades 1 or 2 being the most frequent, but only four $(3.9 \%)$ patients discontinued the treatment due to complications.

Table I depicts the characteristics of all patients and the study sample after selection, with higher prevalence of smokers, alcohol consumers and supraglottic tumors in the group submitted to surgery, and more glottic tumours in the group submitted to radiotherapy. Tumour extension to the anterior commissure was more prevalent in the radiotherapy group. No other significant differences were observed between groups.

\section{Overall survival and cancer-specific survival}

The overall survival rate was $78.6 \%$ at 5 years, and $64.2 \%$ at 10 years. No significant difference in overall survival was observed between groups. The overall survival rate at 5 years was $78.9 \%$ for patients with glottic tumors and $67.9 \%$ for patients with other tumour locations $(\mathrm{p}=0.59)$; $80.9 \%$ for patients with clinical stage I and $70.4 \%$ for clinical stage II $(\mathrm{p}=0.61)$; it was $79.4 \%$ for tumours with staging cT $1 \mathrm{a}, 87.5 \% \mathrm{cT} 1 \mathrm{~b}$ and $73 \% \mathrm{cT} 2(\mathrm{p}=0.72)$. In relation to treatment, the overall survival rates of patients submitted to surgery and radiotherapy were $70.4 \%$ and $77.6 \%$, respectively ( $p=0.43)$ (Fig. 1).

Cancer-specific survival (CSS) rates at 5 and 10 years were $89.7 \%$ and $83.2 \%$, respectively. The CSS rate at 5 years was $85.9 \%$ for patients with glottic tumours and $87.6 \%$ for patients with other tumour locations $(p=0.61) ; 87.1 \%$ for patients with clinical stage I and $88.2 \%$ for patients with clinical stage II ( $\mathrm{p}=0.47) ; 87.3 \%$ for tumors with staging cT1a, 70\% cT1b and $88.2 \%$ cT2 $(\mathrm{p}=0.64)$. In relation to treatment, the CSS rates in patients submitted to surgery and radiotherapy were $89.2 \%$ and $86.7 \%$, respectively $(\mathrm{p}=0.78)$ (Fig. 2). Table II shows the estimates of the pa-

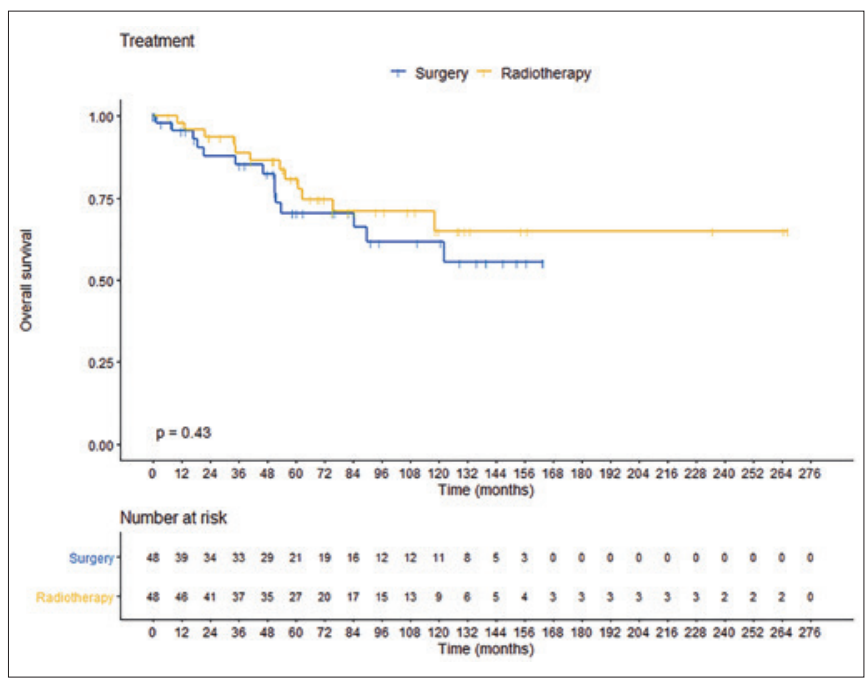

Figure 1. Overall survival by treatment.

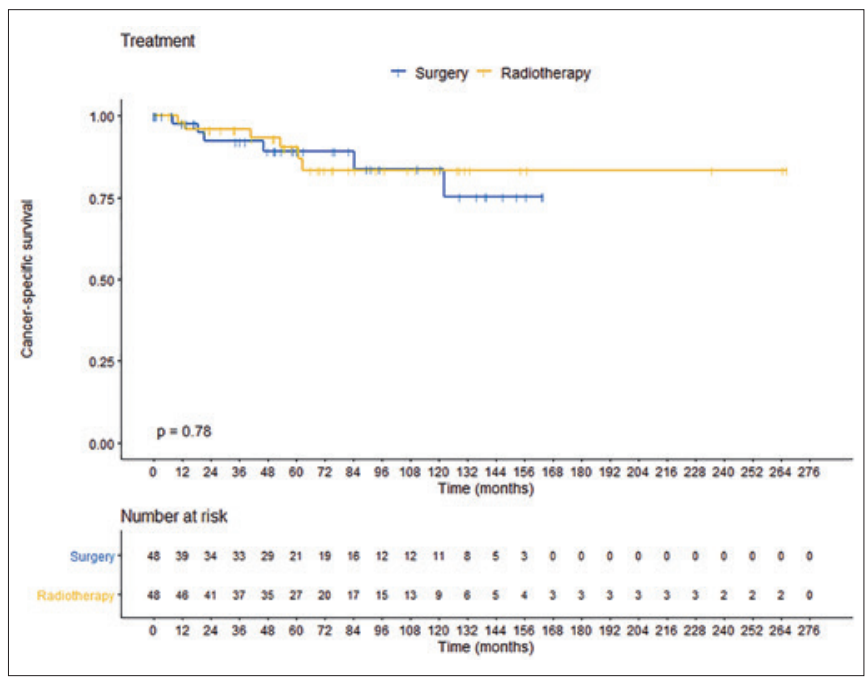

Figure 2. Cancer-specific survival by treatment. 
Table I. Demographic variables related to the patient and tumour extension by categories and frequencies according to the treatment performed before and after the propensity score.

\begin{tabular}{|c|c|c|c|c|c|c|c|}
\hline \multirow[t]{2}{*}{ Variables } & \multirow[t]{2}{*}{ Categories } & \multicolumn{3}{|c|}{ Before propensity score } & \multicolumn{3}{|c|}{ After propensity score } \\
\hline & & $\begin{array}{l}\text { Surgery } \\
\text { Freq. (\%) }\end{array}$ & $\begin{array}{l}\text { Radiotherapy } \\
\text { Freq. (\%) }\end{array}$ & $\mathrm{p}^{*}$ & $\begin{array}{l}\text { Surgery } \\
\text { Freq. (\%) }\end{array}$ & $\begin{array}{c}\text { Radiotherapy } \\
\text { Freq. (\%) }\end{array}$ & $\mathrm{p}$ \\
\hline Gender & Male & $43(89.6 \%)$ & $81(78.6 \%)$ & & $43(89.6 \%)$ & $37(77.1)$ & \\
\hline \multirow[t]{2}{*}{ Age (years) } & $\leq 70$ & 39 (81.3\%) & $73(70.9 \%)$ & 0.247 & $39(81.3 \%)$ & $39(81.3 \%)$ & 1 \\
\hline & $>70$ & $9(18.8 \%)$ & $30(29.1 \%)$ & & $9(18.8 \%)$ & $9(18.8 \%)$ & \\
\hline Education level & Graduation or more & $7(17.9 \%)$ & $21(25.6 \%)$ & & 7 (17.9\%) & $10(27.10 \%)$ & \\
\hline \multirow[t]{2}{*}{ Race } & White & $43(89.6 \%)$ & 97 (94.2\%) & 0.512 & $43(89.6 \%)$ & $46(95.8 \%)$ & 0.488 \\
\hline & No white & $5(10.4 \%)$ & $6(5.8 \%)$ & & $3(6.3 \%)$ & $1(2.1 \%)$ & \\
\hline \multirow[t]{2}{*}{ Smoking } & No & $0(0.0 \%)$ & $16(16.3 \%)$ & 0.003 & $0(0.0 \%)$ & $7(15.2 \%)$ & 0.006 \\
\hline & Yes & $36(75.0 \%)$ & $50(51.0 \%)$ & & $36(75.0 \%)$ & $23(50.0 \%)$ & \\
\hline Alcohol use & Ex-drinker & $7(14.6 \%)$ & $4(4.3 \%)$ & & $7(14.6 \%)$ & $1(2.3 \%)$ & \\
\hline \multirow[t]{2}{*}{ Comorbidities } & No & $20(42.6 \%)$ & $60(60.6 \%)$ & 0.062 & $20(42.6 \%)$ & $28(59.6 \%)$ & 0.074 \\
\hline & Yes & 27 (57.4\%) & $39(39.4 \%)$ & & $27(57.4 \%)$ & $19(40.4 \%)$ & \\
\hline \multirow[t]{4}{*}{$\mathrm{BMI}^{\star \star}$} & Underweight & $1(3.2 \%)$ & $1(1.9 \%)$ & 0.612 & $1(3.2 \%)$ & $1(4.5 \%)$ & 0.609 \\
\hline & Heathy & $15(48.4 \%)$ & $20(37.0 \%)$ & & $15(48.4 \%)$ & $7(31.8 \%)$ & \\
\hline & Excess body weight & $11(35.5 \%)$ & $27(50.0 \%)$ & & $11(35.5 \%)$ & $12(54.5 \%)$ & \\
\hline & Obese & $4(12.9 \%)$ & $6(11.2 \%)$ & & $4(12.9 \%)$ & $2(9.1 \%)$ & \\
\hline \multirow[t]{2}{*}{$A S A^{\star \star \star}$} & 1 & $1(2.4 \%)$ & $4(7.5 \%)$ & 0.622 & $1(2.4 \%)$ & $2(10.0 \%)$ & 0.409 \\
\hline & 2 & $34(82.9 \%)$ & $38 t(71.7 \%)$ & & $34(82.9 \%)$ & $14(70.0 \%)$ & \\
\hline \multirow{2}{*}{$\begin{array}{l}\text { Clinical tumour } \\
\text { stage }\end{array}$} & $\mathrm{T} 1 \mathrm{~b}$ & $2(4.2 \%)$ & $23(22.3 \%)$ & & $2(4.2 \%)$ & $6(12.5 \%)$ & \\
\hline & $\mathrm{T} 2$ & 28 (58.3\%) & $31(30.1 \%)$ & & $28(58.3 \%)$ & $28(58.3 \%)$ & \\
\hline \multirow{2}{*}{$\begin{array}{l}\text { Anterior } \\
\text { commissure }\end{array}$} & No & 45 (93.8\%) & 75 (72.8\%) & 0.006 & $45(93.8 \%)$ & 37 (77.1\%) & 0.04 \\
\hline & Yes & $3(6.3 \%)$ & $28(27.2 \%)$ & & $3(6.3 \%)$ & $11(22.9 \%)$ & \\
\hline \multirow[t]{2}{*}{ Clinical stage } & I & 20 (41.7\%) & $72(69.9 \%)$ & 0.002 & $20(41.7 \%)$ & $20(41.7 \%)$ & 0.999 \\
\hline & $\|$ & 28 (58.3\%) & $31(30.1 \%)$ & & $28(58.3 \%)$ & 28 (58.3\%) & \\
\hline \multirow{2}{*}{$\begin{array}{l}\text { Previous } \\
\text { tracheostomy }\end{array}$} & No & $48(100.0 \%)$ & 101 (98.1\%) & 1.00 & 48 (100\%) & $46(95.8 \%)$ & 0.247 \\
\hline & Yes & $0(0 \%)$ & $2(1.19 \%)$ & & $0(0.0 \%)$ & $2(4.2 \%)$ & \\
\hline
\end{tabular}

"Chi-square test. " Body mass index "“" Physical Status Classification System of American Society of Anesthesiologists. 
Table II. Estimates of the parameters of the Cox regression model for the outcome of overall and cancer-specific survival.

\begin{tabular}{|c|c|c|c|c|c|c|c|c|c|}
\hline \multirow[t]{2}{*}{ Variables } & \multirow[t]{2}{*}{ Categories } & \multicolumn{2}{|c|}{ Overall survival } & \multicolumn{6}{|c|}{ Cancer-specific } \\
\hline & & $\begin{array}{l}\text { No event } \\
(n=70)\end{array}$ & $\begin{array}{c}\text { Event } \\
(n=26)\end{array}$ & HR & $p$ & $\begin{array}{l}\text { No event } \\
(n=84)\end{array}$ & $\begin{array}{c}\text { Event } \\
(n=12)\end{array}$ & HR & $p$ \\
\hline \multirow[t]{2}{*}{ Gender } & Female & 13 (18.6\%) & $3(11.5 \%)$ & Ref & & 15 (17.9\%) & $1(8.3 \%)$ & Ref & 0.385 \\
\hline & Male & 57 (81.4\%) & 23 (88.5\%) & 1.712 & 0.381 & $69(82.1 \%)$ & $11(91.7 \%)$ & 2.478 & \\
\hline \multirow[t]{2}{*}{ Age (years) } & $\leq 70$ & $56(80 \%)$ & $22(84.6 \%)$ & Ref & & 67 (79.8\%) & $11(91.7 \%)$ & Ref & 0.377 \\
\hline & $>70$ & $14(20 \%)$ & 4 (15.4\%) & 0.784 & 0.655 & $17(20.2 \%)$ & $1(8.3 \%)$ & 0.398 & \\
\hline \multirow[t]{2}{*}{ Race } & White & 65 (92.9\%) & 24 (92.3\%) & Ref & & $53(80.3 \%)$ & $6(60.0 \%)$ & Ref & 0.152 \\
\hline & No white & $5(7.1 \%)$ & $2(7.7 \%)$ & 2.359 & 0.250 & $13(19.7 \%)$ & $4(40.0 \%)$ & 2.550 & \\
\hline \multirow[t]{2}{*}{$\begin{array}{l}\text { Education } \\
\text { degree level }\end{array}$} & $\begin{array}{c}\text { No } \\
\text { graduation }\end{array}$ & 44 (78.6\%) & $15(75 \%)$ & Ref & & 77 (91.7\%) & $12(100 \%)$ & & \\
\hline & $\begin{array}{c}\text { Graduation or } \\
\text { more }\end{array}$ & $12(21.4 \%)$ & $5(25 \%)$ & 1.247 & 0.670 & $7(8.3 \%)$ & $0(0.0 \%)$ & $\mathrm{NE}^{*}$ & \\
\hline \multirow[t]{3}{*}{ Smoking } & No & $6(8.8 \%)$ & $1(3.8 \%)$ & Ref & & $7(8.5 \%)$ & $0(0.0 \%)$ & $\mathrm{NE}^{*}$ & \\
\hline & Yes & 41 (60.3\%) & $18(69.2 \%)$ & 2.495 & 0.374 & $50(61.0 \%)$ & $9(75.0 \%)$ & $\mathrm{NE}^{*}$ & \\
\hline & Ex-smoker & 21 (30.9\%) & 7 (26.9\%) & 2.128 & 0.480 & 25 (30.5\%) & $3(25.0 \%)$ & $\mathrm{NE}^{*}$ & \\
\hline \multirow[t]{3}{*}{ Alcohol use } & No & $24(36.4 \%)$ & $9(34.6 \%)$ & Ref & & $28(35.0 \%)$ & $5(41.7 \%)$ & $\mathrm{NE}^{*}$ & \\
\hline & Yes & $38(57.6 \%)$ & $13(50 \%)$ & 1.071 & 0.874 & $44(55.0 \%)$ & 7 (58.3\%) & $\mathrm{NE}^{*}$ & \\
\hline & Ex-drinker & $4(6.1 \%)$ & 4 (15.4\%) & 3.041 & 0.066 & $8(10.0 \%)$ & $0(0.0 \%)$ & $\mathrm{NE}^{*}$ & \\
\hline \multirow[t]{2}{*}{ Comorbidities } & No & 35 (51.5\%) & $13(50 \%)$ & Ref & & 42 (51.2\%) & $6(50.0 \%)$ & Ref & 0.688 \\
\hline & Yes & 33 (48.5\%) & 13 (50\%) & 0.792 & 0.553 & 40 (48.8\%) & $6(50.0 \%)$ & 0.793 & \\
\hline \multirow[t]{2}{*}{$\mathrm{BMI}^{\star \star}$} & No heathy & $24(57.1 \%)$ & 7 (63.6\%) & Ref & & 28 (58.3\%) & $3(60.0 \%)$ & & 0.933 \\
\hline & Heathy & 18 (42.9\%) & 4 (36.4\%) & 0.993 & 0.992 & $20(41.7 \%)$ & $2(40.0 \%)$ & 1.081 & \\
\hline \multirow[t]{2}{*}{$A S A^{\star \star \star}$} & 1 or 2 & 39 (84.8\%) & $12(80 \%)$ & Ref & & 45 (83.3\%) & $6(85.7 \%)$ & Ref & 0.979 \\
\hline & 3 or 4 & 7 (15.2\%) & 3 (20\%) & 1.386 & 0.617 & $9(16.7 \%)$ & 1 (14.3\%) & 0.972 & \\
\hline \multirow[t]{2}{*}{ Tumour site } & No glottic & $23(32.9 \%)$ & $12(46.2 \%)$ & Ref & & 31 (36.9\%) & 4 (33.3\%) & Ref & 0.616 \\
\hline & Glottic & 47 (67.1\%) & $14(53.8 \%)$ & 0.808 & 0.588 & $53(63.1 \%)$ & 8 (66.7\%) & 1.359 & \\
\hline \multirow{3}{*}{$\begin{array}{l}\text { Clinical tumour } \\
\text { stage }\end{array}$} & $1 a$ & 26 (37.1\%) & $6(23.1 \%)$ & Ref & & $28(33.3 \%)$ & 4 (33.3\%) & Ref & 0.586 \\
\hline & $1 b$ & $5(7.1 \%)$ & 3 (11.5\%) & 1.599 & 0.507 & $6(7.1 \%)$ & 2 (16.7\%) & 1.604 & 0.669 \\
\hline & 2 & 39 (55.7\%) & $17(65.4 \%)$ & 1.412 & 0.468 & $50(59.5 \%)$ & $6(50.0 \%)$ & 0.759 & \\
\hline \multirow[t]{2}{*}{ Clinical stage } & I & 31 (44.3\%) & $9(34.6 \%)$ & Ref & & 34 (40.5\%) & $6(50.0 \%)$ & Ref & 0.478 \\
\hline & $\|$ & 39 (55.7\%) & 17 (65.4\%) & 1.236 & 0.608 & 50 (59.5\%) & $6(50.0 \%)$ & 0.664 & \\
\hline \multirow{2}{*}{$\begin{array}{l}\text { Anterior } \\
\text { commissure }\end{array}$} & No & 61 (87.1\%) & $21(80.8 \%)$ & Ref & & 72 (85.7\%) & 10 (83.3\%) & Ref & 0.934 \\
\hline & Yes & 9 (12.9\%) & $5(19.2 \%)$ & 1.298 & 0.601 & $12(14.3 \%)$ & 2 (16.7\%) & 1.066 & \\
\hline \multirow[t]{2}{*}{ Treatment } & Surgery & 34 (48.6\%) & $14(53.8 \%)$ & Ref & & $42(50.0 \%)$ & $6(50.0 \%)$ & Ref & 0.784 \\
\hline & Radiotherapy & $36(51.4 \%)$ & $12(46.2 \%)$ & 0.736 & 0.436 & $42(50.0 \%)$ & $6(50.0 \%)$ & 0.854 & \\
\hline
\end{tabular}

"There are no numbers to evaluate "Body mass index. "' Physical Status Classification System of American Society of Anesthesiologists.

rameters of the Cox regression model for the outcome of overall and cancer-specific survival and Figure 2 shows CSS by treatment.

\section{Local recurrence-free survival}

The local recurrence-free survival (LRFS) rate was $76.5 \%$ at 5 years, and $67.6 \%$ at 10 years. The recurrence rate was $12.5 \%$ after surgery and $37.5 \%$ after radiotherapy $(\mathrm{p}=0.021)$. Patients classified as ASA 3 or 4 with glottic tumours who underwent radiotherapy had a higher risk of local recurrences. Conversely, no significance differences were seen for gender, tobacco and alcohol exposure, pathological classification and tumour extension for anterior commissure. The LRFS rate was $76.5 \%$ for patients with glottic tumours and $83.7 \%$ for patients with tumours at other locations ( $\mathrm{p}=0.048) ; 79.3 \%$ for patients with clinical stage I disease and $79.3 \%$ for patients with clinical stage II $(\mathrm{p}=0.53)$; and $79.2 \%$ for tumours staged cT1a, $74.3 \%$ $\mathrm{cT} 1 \mathrm{~b}$ and $79.2 \% \mathrm{cT} 2(\mathrm{p}=0.73)$. With respect to treatment, 


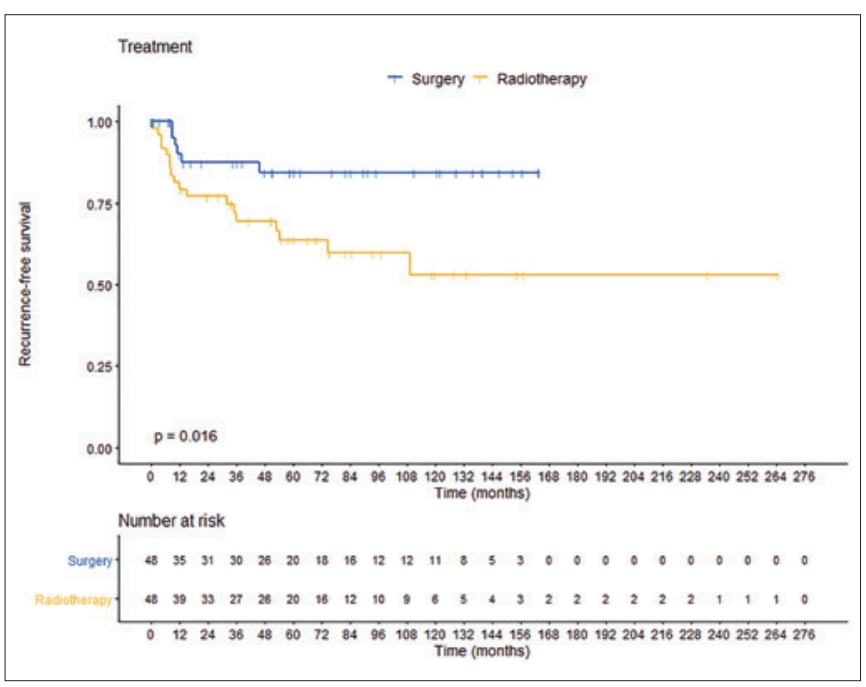

Figure 3. Local recurrence-free survival by treatment.

LRFS rates of patients submitted to surgery and radiotherapy were $84.3 \%$ and $63.6 \%$, respectively $(\mathrm{p}=0.016)$ (Fig. 3 , Tab. III).

Among patients who underwent surgery, six had local recurrence, with one frontolateral partial laryngectomy and three total laryngectomies with neck dissection and adjuvant radiotherapy as salvage procedures. Chemoradiotherapy as an organ preservation strategy after local recurrence was performed in two patients. In patients treated with radiotherapy, 18 presented local recurrence, 14 were submitted to total laryngectomy with neck dissection, two to frontolateral laryngectomy, one supracricoid laryngectomy and one to endoscopic transoral surgery. Local recurrence rates were higher in patients with supraglottic tumours staged by cT2 and treated with radiotherapy (Tab. IV).

\section{Laryngeal preservation}

The laryngeal preservation rate was $78.2 \%$. No correlation was found between the probability of laryngeal preservation and the variables analysed, although patients with ASA classification 3 or 4 who underwent radiotherapy presented a tendency towards higher risk of laryngeal loss, but without statistical significance. Among the 48 patients who underwent surgery, seven had a non-functional larynx at the end of follow-up: three were submitted to salvage total laryngectomy, two presented chronic aspiration and had a percutaneous gastrostomy and two had permanent tracheostomy due to laryngeal stenosis. In the patients treated by radiotherapy, except for 14 who underwent salvage total laryngectomy, the remaining had a functioning larynx at the time of assessment. Table $\mathrm{V}$ shows the estimates of the parameters of the simple logistic regression model for la-

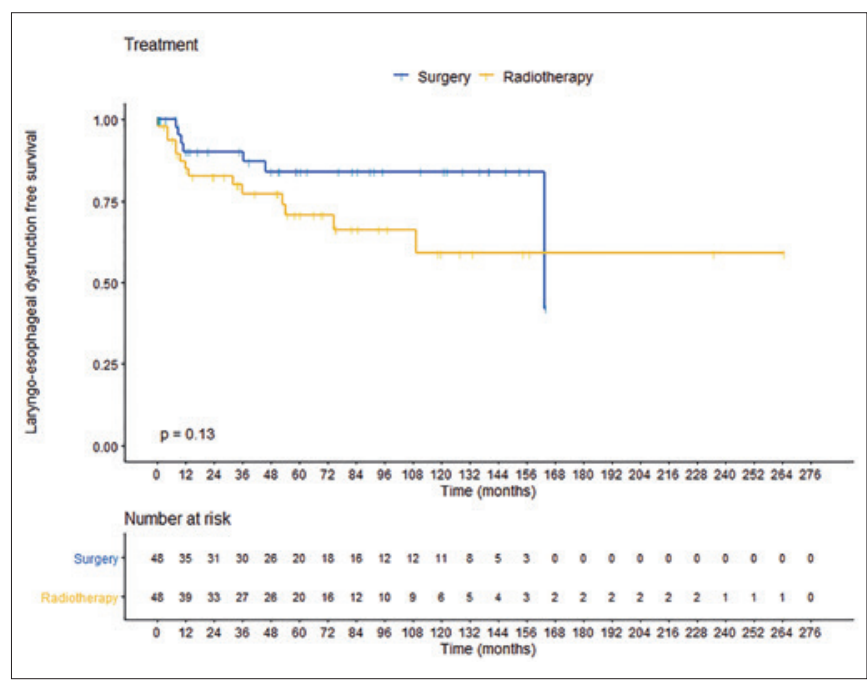

Figure 4. Laryngo-oesophageal dysfunction free survival by treatment.

ryngeal preservation and Figure 4 shows laryngo-oesophageal dysfunction-free survival curves.

\section{Discussion}

The treatment of patients with LSCC at clinical stages cT1N0 or cT2N0 depends on various factors such as availability of infrastructure for each treatment modality, the patient's physical condition, multidisciplinary team preferences and patient choice, especially regarding voice preservation together with characteristics of the tumours, and especially its primary location. Thus, random prospective studies for this group of patients have not been developed, with the exception of Ogol'tsova et al. (1990) cited by Warner et al. (2014), which has some methodological issues.

Data from the literature and previous analysis of this study showed a trend towards the use of radiotherapy in patients with glottic tumours and the use of surgery in patients with supraglottic tumours or stage cT2N0. Thus, the propensity score was used to reduce the impact of selection bias in outcomes. This methodology has been largely used in medicine and is considered a good option for randomised prospective clinical studies ${ }^{11}$.

OS and CSS had no significant association with clinical variables. Although Guimarães et al. (2018) described a higher OS and CSS rates for patients with glottic tumours cTis/cT1a treated with surgery compared to those treated with radiotherapy. Similar results were found in the study by Vaculik et al. (2019) on patients with cT1 stage glottic tumours. In contrast, the systematic reviews by Yoo et al. (2014) and Warner et al. (2014) found no significant differ- 
Table III. Estimates of the parameters of the Cox regression model for the outcome of local recurrence-free survival.

\begin{tabular}{|c|c|c|c|c|c|c|c|}
\hline \multirow[t]{2}{*}{ Variables } & \multirow[t]{2}{*}{ Categories } & \multicolumn{2}{|c|}{ Local recurrence } & \multirow[t]{2}{*}{ HR } & \multicolumn{2}{|c|}{ Cl (95\%) } & \multirow[t]{2}{*}{$\mathrm{p}$} \\
\hline & & $\begin{array}{l}\text { No event } \\
(\mathrm{n}=72)\end{array}$ & $\begin{array}{c}\text { Event } \\
(n=24)\end{array}$ & & Lower & Higher & \\
\hline \multirow[t]{2}{*}{ Gender } & Female & 13 (18.1\%) & $3(12.5 \%)$ & Ref & & & \\
\hline & Male & $59(81.9 \%)$ & $21(87.5 \%)$ & 1.594 & 0.475 & 5.347 & 0.450 \\
\hline \multirow[t]{2}{*}{ Age (years) } & $\leq 70$ & $55(76.4 \%)$ & 23 (95.8\%) & Ref & & & \\
\hline & $>70$ & $17(23.6 \%)$ & $1(4.2 \%)$ & 0.164 & 0.022 & 1.217 & 0.077 \\
\hline \multirow[t]{2}{*}{ Race } & White & $65(90.3 \%)$ & 24 (100\%) & & & & \\
\hline & No white & $7(9.7 \%)$ & $0(0.0 \%)$ & NA & & & \\
\hline \multirow{2}{*}{$\begin{array}{l}\text { Education degree } \\
\text { level }\end{array}$} & No graduation & $43(76.8 \%)$ & 16 (80.\%) & Ref & & & \\
\hline & Graduation or more & $13(23.2 \%)$ & 4 (20.0\%) & 0.866 & 0.289 & 2.595 & 0.798 \\
\hline \multirow[t]{3}{*}{ Smoking } & No & $6(8.6 \%)$ & $1(4.2 \%)$ & Ref & & & \\
\hline & Yes & $44(62.9 \%)$ & $15(62.5 \%)$ & 2.012 & 0.265 & 15.251 & 0.499 \\
\hline & Ex-smoker & $20(28.6 \%)$ & 8 (33.3\%) & 2.233 & 0.279 & 17.883 & 0.449 \\
\hline \multirow[t]{3}{*}{ Alcohol use } & No & $25(36.8 \%)$ & 8 (33.3\%) & Ref & & & \\
\hline & Yes & $36(52.9 \%)$ & $15(62.5 \%)$ & 1.406 & 0.596 & 3.320 & 0.436 \\
\hline & Ex-drinker & 7 (10.3\%) & $1(4.2 \%)$ & 0.734 & 0.091 & 5.890 & 0.771 \\
\hline \multirow[t]{2}{*}{ Comorbidities } & No & $35(50.0 \%)$ & 13 (54.2\%) & Ref & & & \\
\hline & Yes & $35(50.0 \%)$ & $11(45.8 \%)$ & 0.663 & 0.296 & 1.483 & 0.317 \\
\hline \multirow[t]{2}{*}{ BMI } & No heathy & 25 (59.5\%) & $6(54.5 \%)$ & Ref & & & \\
\hline & Heathy & $17(40.5 \%)$ & $5(45.5 \%)$ & 1.163 & 0.354 & 3.821 & 0.803 \\
\hline \multirow[t]{2}{*}{ ASA" $^{*}$} & 1 or 2 & $42(89.4 \%)$ & $9(64.3 \%)$ & Ref & & & \\
\hline & 3 or 4 & $5(10.6 \%)$ & $5(35.7 \%)$ & 3.092 & 1.030 & 9.285 & 0.044 \\
\hline \multirow{2}{*}{ Tumour site } & No glottic & $30(41.7 \%)$ & $5(20.8 \%)$ & Ref & & & \\
\hline & Glottic & $42(58.3 \%)$ & 19 (79.2\%) & 2.705 & 1.008 & 7.261 & 0.048 \\
\hline \multirow{3}{*}{$\begin{array}{l}\text { Clinical tumour } \\
\text { stage }\end{array}$} & $1 a$ & $23(31.9 \%)$ & 9 (37.5\%) & Ref & & & \\
\hline & $1 b$ & $6(8.3 \%)$ & $2(8.3 \%)$ & 0.695 & 0.150 & 3.219 & 0.642 \\
\hline & 2 & $43(59.7 \%)$ & $13(54.2 \%)$ & 0.718 & 0.306 & 1.681 & 0.445 \\
\hline \multirow[t]{2}{*}{ Clinical stage } & I & $29(40.3 \%)$ & $11(45.8 \%)$ & Ref & & & \\
\hline & $\|$ & $43(59.7 \%)$ & 13 (54.2\%) & 0.775 & 0.347 & 1.731 & 0.534 \\
\hline \multirow{2}{*}{$\begin{array}{l}\text { Anterior } \\
\text { commissure }\end{array}$} & No & $62(86.1 \%)$ & $20(83.3 \%)$ & Ref & & & \\
\hline & Yes & 10 (13.9\%) & $4(16.7 \%)$ & 1.021 & 0.349 & 2.991 & 0.969 \\
\hline \multirow[t]{2}{*}{ Treatment } & Surgery & 42 (58.3\%) & 6 (25.0\%) & Ref & & & \\
\hline & Radiotherapy & $30(41.7 \%)$ & $18(75.0 \%)$ & 2.967 & 1.177 & 7.479 & 0.016 \\
\hline
\end{tabular}

"Body mass index. "' Physical Status Classification System of American Society of Anesthesiologists.

Table IV. Local recurrence-free survival estimates at 5 years by tumour location and staging according to treatment.

\begin{tabular}{lccccc} 
Variables & \multicolumn{2}{c}{ Categories } & \multicolumn{2}{c}{ Treatment } & p \\
& & & Surgery & Radiotherapy & \\
Tumour site/Stage & Glottic & & $76.5 \%$ & $63.2 \%$ & 0.949 \\
& & T1 & $80.0 \%$ & $65.0 \%$ & 0.286 \\
& Supraglottic & T2 & $100.0 \%$ & $100.0 \%$ & 1 \\
& & T1 & $95.7 \%$ & $50.0 \%$ & 0.04 \\
\hline
\end{tabular}


Table V. Estimates of parameters of the simple logistic regression model for laryngeal preservation.

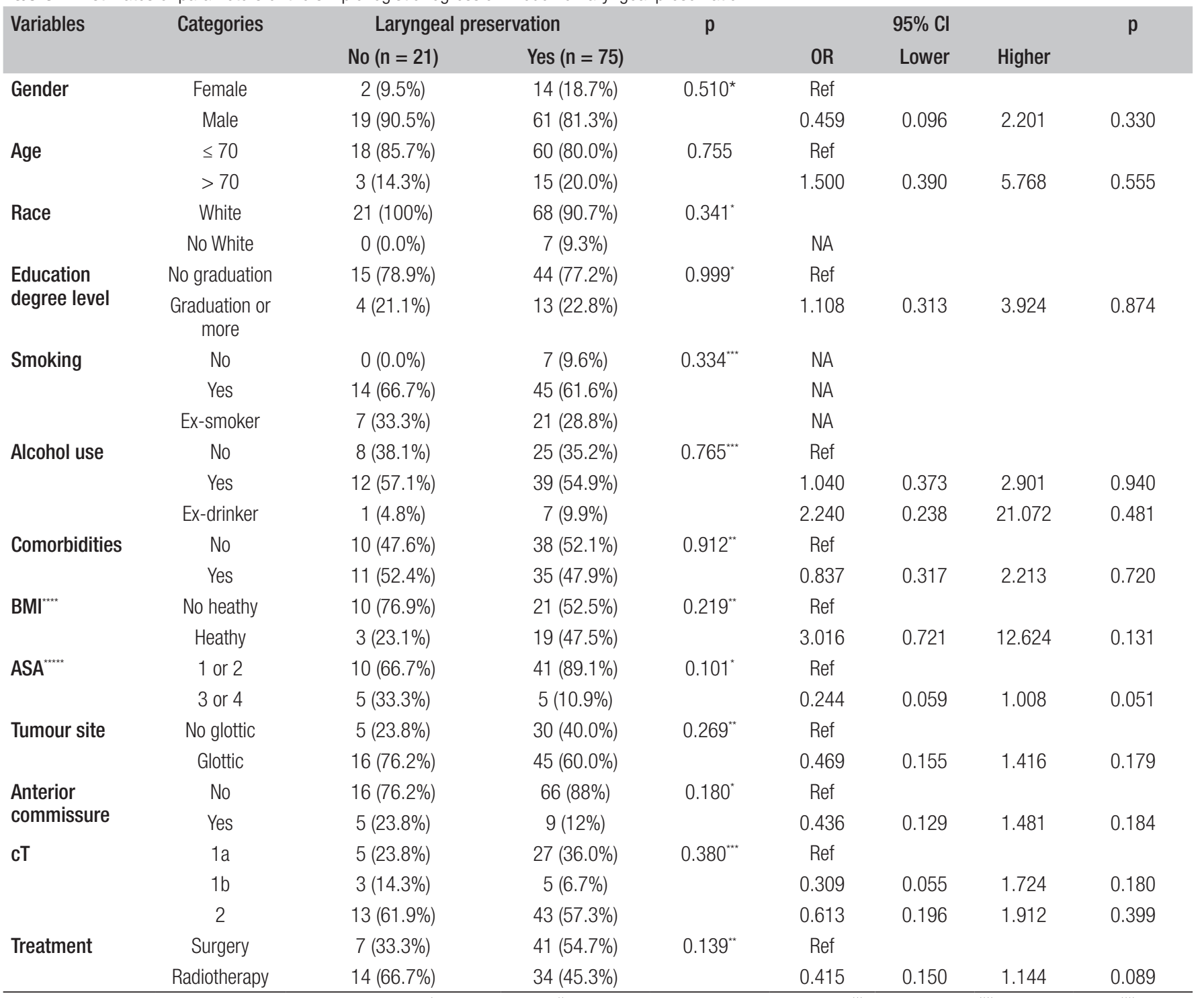

NA: Not available due to insufficient number for calculation OR. ${ }^{*}$ Fisher exact test. "* Chi-square test with continuity correction. ${ }^{\text {"** }}$ Chi-square test. ${ }^{* * *}$ Body mass index. ${ }^{* *+*}$ Physical Status Classification System of American Society of Anesthesiologists.

ences in OS and CSS between surgery and radiotherapy in patients with early laryngeal cancer.

The local recurrence-free survival rate was lower in patients classified as ASA 3 or 4, with glottic tumours, and submitted to radiotherapy. These patients were preferably treated with radiotherapy because of the high risk of surgery and to improve the quality of voice preservation, respectively. Kowalski et al. (1993) evaluated 145 patients treated between 1954 and 1990 and described a higher rate of local recurrences in patients undergoing radiotherapy $(29.5 \%)$ compared to those who underwent surgery $(10 \%)$. Of course, differences in technology in diagnosing and treating these tumors has a definite impact on clinical outcomes.
The laryngeal preservation rate has been controversially reported in the literature. Some authors demonstrated higher rates of preservation in patients who underwent surgery ${ }^{8,12-15}$, whereas others demonstrated that radiotherapy shows similar results to surgery with even better functional results ${ }^{3,16,17}$. In the present study, we observed a higher tendency for laryngeal preservation in patients who underwent surgery compared with those who underwent radiotherapy, although the difference was not statistically significant. Compared with surgery, radiotherapy showed higher rates of local recurrence (12.5 vs 37.5\%) and $22 \%$ were candidates for salvage partial laryngectomy. In this scenario, partial laryngectomy presented high 
rates of local complications, longer decannulation and enteral feeding times, and a higher risk of second recurrences. Therefore, patients must be carefully selected for this treatment modality ${ }^{18,19}$.

Long-term laryngeal preservation in patients who had local recurrence is dependent on the patient's physical condition, the possibility of proper follow up and the experience of the multidisciplinary team in performing partial salvage laryngectomy ${ }^{20,21}$. These factors should also be considered when choosing initial treatment. Furthermore, the initial therapeutic choice should also consider the outcome of the salvage treatment.

In pathological staging, $16.7 \%$ of cT1a tumours were restaged for pT2; of 28 cT2 tumours, $17(60.7 \%)$ had a different final pathological staging: six were pT1a (21.4\%), six were pT3 $(21.4 \%)$ and five changed to pT4a (17.8\%) due to laryngeal cartilage in the anterior commissure invasion (not detected on previous CT for pre-surgery staging). Therefore, the higher incidence of local recurrence in patients who underwent radiotherapy than in those who underwent surgery could be related not only to biological factors, but also to inappropriate clinical tumour stage. Thus, accurate clinical staging is essential for adequate treatment, especially in cT2.

Regarding the radiotherapy group, the rate of radiotherapy interruption was only $3.9 \%$, and patients were treated with doses of radiation described in the literature: a median of 66 Gy in cT1a tumours, 64.2 Gy in cT1b tumours and 69.7 Gy in cT2 tumours ${ }^{22,23}$.

Despite the use of the PS method to match patients according to treatment modality, this study has limitations inherent to the retrospective cohort design. Unlike randomised prospective studies where groups are matched by known and unknown variables, the propensity score method does not allow matching by all characteristics. This study also demonstrated additional significant differences between the groups even after PS matching. A high prevalence of alcohol and tobacco consumers and cT2N0 tumours was observed in the surgery group, whereas the group treated with radiotherapy had a higher prevalence of cT1aN0 glottic tumors. These characteristics may indicate a bias in group selection. These types of biases have been a limitation in a variety of retrospective studies ${ }^{24}$ in comparison to randomised prospective trials ${ }^{25}$. The presence of missing values for some variables is also a limitation, such as the possibility of adequate exposure of the larynx in patients who underwent radiotherapy, whether the therapeutic choice was made mainly by the medical team or the patient, lack of information regarding final vocal quality, and treatment costs according to therapeutic modality.

\section{Conclusions}

Patients with LSCC at clinical stages I/II treated with surgery or radiotherapy at a reference oncology centre with multidisciplinary teams and regular post-treatment followup seems to have similar overall and cancer-specific survival. However, even in this scenario, treatment with radiotherapy is associated with a higher risk of local recurrence, not only for possible inappropriate clinical staging, but also due to biological factors related to radiotherapy resistance. Thus, the appropriate follow-up and expertise of performing salvage partial laryngectomy after local recurrence after radiotherapy is essential to achieve similar laryngeal preservation rates.

\section{References}

1 Kowalski LP, Batista MB, Santos CR, et al. Prognostic factors in glottic carcinoma clinical stage I and II treated by surgery or radiotherapy. Am J Otolaryngol 1993;14:122-127.

2 Ansarin M, Zabrodsky M, Bianchi L, et al. Endoscopic CO2 laser surgery for early glottic cancer in patients who are candidates for radiotherapy: results of a prospective nonrandomized study. Head Neck 2006;28:121-125. https://doi.org/10.1002/hed.20301

3 Jones DA, Mendenhall CM, Kirwan J, et al. Radiation therapy for management of $\mathrm{t} 1-\mathrm{t} 2$ glottic cancer at a private practice. Am J Clin Oncol 2010;33:587-590. https://doi.org/10.1097/COC.0b013e3181beaab0

4 Thomas L, Drinnan M, Natesh B, et al. Open conservation partial laryngectomy for laryngeal cancer: a systematic review of English language literature. Cancer Treat Rev 2012;38:203-211. https://doi. org/10.1016/j.ctrv.2011.05.010

5 O’Hara J, Markey A, Homer JJ. Transoral laser surgery versus radiotherapy for tumour stage $1 \mathrm{a}$ or $1 \mathrm{~b}$ glottic squamous cell carcinoma: systematic review of local control outcomes. J Laryngol Otol 2013;127:732-738. https://doi.org/10.1017/S0022215113001400

6 Warner L, Chudasama J, Kelly CG, et al. Radiotherapy versus open surgery versus endolaryngeal surgery (with or without laser) for early laryngeal squamous cell cancer. Cochrane Database Syst Rev 2014;12:CD002027. https://doi.org/ 10.1002/14651858.CD002027

7 Yoo J, Lacchetti C, Hammond JA, et al. Role of endolaryngeal surgery (with or without laser) versus radiotherapy in the management of early (T1) glottic cancer: a systematic review. Head Neck 2014;36:18071819. https://doi.org/10.1002/hed.23504

8 Hendriksma M, Heijnen BJ, Sjögren EV. Oncologic and functional outcomes of patients treated with transoral $\mathrm{CO} 2$ laser microsurgery or radiotherapy for $\mathrm{T} 2$ glottic carcinoma: a systematic review of the literature. Curr Opin Otolaryngol Head Neck Surg 2018;26:84-93. https://doi.org/10.1097/MOO.0000000000000438.

9 Guimarães AV, Dedivitis RA, Matos LL, et al. Comparison between transoral laser surgery and radiotherapy in the treatment of early glottic cancer: a systematic review and meta-analysis. Sci Rep 2018;8:11900. https://doi.org/10.1038/s41598-018-30218-x

10 Amin MB, Edge SB, Greene FL, et al. AJCC Cancer Staging Manual. Eighth edition. New York: Springer; 2017. Larynx; pp. 46-64.

11 Loux TM. Randomization, matching, and propensity scores in the design and analysis of experimental studies with measured baseline covariates. Stat Med 2015;34:558-570. https://doi.org/10.1002/ $\operatorname{sim} .6361$ 
12 Abdurehim Y, Hua Z, Yasin Y, et al. Transoral laser surgery versus radiotherapy: systematic review and meta-analysis for treatment options of T1a glottic cancer. Head Neck 2012;34:23-33. https://doi. org/10.1002/hed.21686

13 Succo G, Crosetti E, Bertolin A, et al. Benefits and drawbacks of open partial horizontal laryngectomies. Part A: early-to intermediatestage glottic carcinoma. Head Neck 2016;38:333-340. https://doi. org/10.1002/hed.23997

14 Ansarin M, Cattaneo A, De Benedetto L, et al. Retrospective analysis of factors influencing oncologic outcome in 590 patients with earlyintermediate glottic cancer treated by transoral laser microsurgery. Head Neck 2017;39:71-81. https://doi.org/10.1002/hed.24534

15 Vaculik MF, MacKay CA, Taylor SM, et al. Systematic review and meta-analysis of $\mathrm{T} 1$ glottic cancer outcomes comparing $\mathrm{CO}(2)$ transoral laser microsurgery and radiotherapy. J Otolaryngol Head Neck Surg 2019;48:44. https://doi.org/10.1186/s40463-019-0367-2

16 Rosier JF, Grégoire V, Counoy H, et al. Comparison of external radiotherapy, laser microsurgery and partial laryngectomy for the treatment of T1N0M0 glottic carcinomas: a retrospective evaluation. Radiother Oncol 1998;48:175-183. https://doi.org/10.1016/ s0167-8140(98)00058-9

17 Aaltonen LM, Rautiainen N, Sellman J, et al. Voice quality after treatment of early vocal cord cancer: a randomized trial comparing laser surgery with radiation therapy. Int J Radiat Oncol Biol Phys 2014;90:255-260. https://doi.org/10.1016/j.ijrobp.2014.06.032

18 Locatello LG, Cannavicci A, Gallo O. Prognostic impact of initial treatment in surgically salvaged recurrences of early glottic can- cer. Laryngoscope 2019;129:2328-2333. https://doi.org/10.1002/ lary. 27702

19 Bertolin A, Lionello M, Ghizzo M, et al. Salvage open partial horizontal laryngectomy after failed radiotherapy: a multicentric study. Laryngoscope 2020;130:431-436. https://doi.org/10.1002/lary.27959

20 Pontes P, Brasil Ode O, Amorim Filho Fde S, et al. Radiotherapy for early glottic cancer and salvage surgery after recurrence. Braz J Otorhinolaryngol 2011;77:299-302. https://doi.org/10.1590/ s1808-86942011000300005

21 Agra IM, Ferlito A, Takes RP, et al. Diagnosis and treatment of recurrent laryngeal cancer following initial nonsurgical therapy. Head Neck 2012;34:727-735. https://doi.org/10.1002/hed.21739

22 Mendenhall WM, Parsons JT, Stringer SP, et al. Management of Tis, T1, and T2 squamous cell carcinoma of the glottic larynx. Am J Otolaryngol 1994;15:250-257. https://doi.org/10.1016/0196-0709(94)90091-4

23 Franchin G, Minatel E, Gobitti C, et al. Radiation treatment of glottic squamous cell carcinoma, stage I and II: analysis of factors affecting prognosis. Int J Radiat Oncol Biol Phys 1998;40:541-548. https://doi. org/10.1016/s0360-3016(97)00768-2

24 Enarson DA, Kennedy SM, Miller DL. Choosing a research study design and selecting a population to study. Int J Tuberc Lung Dis 2004;8:1151-1156.

25 Anglemyer A, Horvath HT, Bero L. Healthcare outcomes assessed with observational study designs compared with those assessed in randomized trials. Cochrane Database Syst Rev 2014;9:MR000034. https://doi.org/10.1002/14651858.MR000034 